\title{
Determination of Serum Nucleotidase with Cytidine Monophosphate as Substrate, (I)
}

\author{
By P. J. van der Kooij, J.-P. Persijn, W. van der Slik and C. B. Korsten \\ From the Department of Clinical Chemistry (Head: Dr. W. van der Slik), University Hospital, Leiden, and the \\ Department of Clinical Chemistry (Head: Dr. J.-P. Persijn), Netherlands Cancer Institute, Amsterdam, The Nether- \\ lands.
}

(Eingegangen am 15. Oktober 1974/5. Februar 1975)

\begin{abstract}
This paper deals with a new method for the determination of serum nuclcotidase (EC 3.1.3.5). The assay is performed with cytidine5 -monophosphate as substrate, followed by deamination of the generated cytidine. The principle of the method and the determination of the liberated ammonia by the Berthelot indophenol-reaction are comparable to the Persijn - van der Slik method in which adenosine5 -monophosphate is used as substrate. The correlation between the results obtained with these two methods was found to be good; the new method has the advantage of higher sensitivity.
\end{abstract}

Es wird über eine neue Methode zur Bestimmung der Aktivität der 5'-Nucleotidase (EC 3.1.3.5) im Serum berichtet. Cytidin-5'-monophosphat wird durch 5'-Nucleotidase gespalten und das gebildete Cytidin durch Cytidindeaminase desaminiert.

Das Prinzip der Methode und die Bestimmung des freigesetzten Ammoniak sind ähnlich der Persijn - van der Slik-Methode, wclche Adenosin-5' monophosphat verwendet.

Beide Methoden zeigen eine gute Korrelation, das neue Verfahren hat aber den Vorteil größerer Empfindlichkcit.

Many methods are in use for the determination of serum $5^{\prime}$-nucleotidase ${ }^{1}$ ), which is normally measured on the basis of its activity towards AMP at pH 7.5, after correction for non-specific phosphatases. In our opinion, the most attractive of these methods is that of Persijn and van der Slik (1-5).

This procedure uses AMP as substrate, followed by deamination of the generated adenosine by adenosine deaminase, after which the liberated ammonia is determined by the sensitive Berthelot indophenol-reaction.

Other substrates have been mentioned by some authors $(6,7,8)$. For example, they also determined 5 '-nucleotidase as the activity towards CMP, but, perhaps partly because of non-optimal conditions, their results were contradictory and, as a consequence, AMP remained the substrate of choice.

In a preliminary investigation, however, we used a method for the determination of the liberated inorganic phosphate and found that activities with CMP were almost double those obtained with AMP as substrate.

We decided to investigate this point in more detail, using the 5 '-nucleotidase ammonia method, but for this purpose we had to obtain a preparation with

\footnotetext{
1) Enzymes: 5'-Nucleotidase (5'-Ribonucleotide-phosphohydrodrolase) EC 3.1.3.5; Adenosine deaminase EC 3.5.4.4; Cytidine deaminase EC 3.5.4.5.
}

cytidine deaminase activity (to be used as second enzyme to measure the cytidine) because cytidine deaminase is (still) not available commercially.

A method was developed for the extraction of cytidine deaminase from Escherichia coli cells. With this preparation, all parameters of the $5^{\prime}$-nucleotidase determination with CMP and the correlation between the AMP and CMP methods were determined.

The principle on which the new method is based is as follows:

cytidine- $5^{\prime}$-monophosphate $\stackrel{5^{\prime} \text {-nucleotidase }}{\longrightarrow} \mathrm{P}_{\mathrm{i}}+$ cytidine $\stackrel{\text { cytidine deaminase }}{\longrightarrow}$ uridine $+\mathrm{NH}_{4}^{+}$

$$
\downarrow
$$

indophenol reaction

$\downarrow$

blue colour

\section{Material and Methods}

Preparation of crude cytidine deaminase extract

E. coli B (wild type; Medisch Biologisch Laboratorium, T. N. O., Holland) was grown at $37^{\circ} \mathrm{C}$ overnight in Vogel-Bonner medium $\left(0.2 \mathrm{~g} \mathrm{Mg} \mathrm{SO}_{4} ; 7 \mathrm{H}_{2} \mathrm{O}, 2.0 \mathrm{~g}\right.$ citric acid, $10.0 \mathrm{~g} \mathrm{~K}_{2} \mathrm{HPO}_{4}$, and $3.5 \mathrm{~g} \mathrm{Na}\left(\mathrm{NH}_{4}\right) \mathrm{HPO}_{4}$ dissolved in distilled water, diluted to 1 litre and sterilised for $20 \mathrm{~min}$ at $120^{\circ} \mathrm{C}$ ) with $0.25 \mathrm{~g}$ glucose added per litre culture fluid. The next morning, $4 \mathrm{~g}$ glucose and $2 \mathrm{~g}$ caseine were added per litre fluid and after further growth for 2-3 hours the culture reached the exponential phase (cxtinction at $550 \mathrm{~nm}$ about 0,8 ) and the cells were 
harvested by centrifugation ( $15 \mathrm{~min}, 6,000 \mathrm{rpm}$ ). The pellet was taken up in phosphate buffer $(0.01 \mathrm{~mol} / \mathrm{l} ; \mathrm{pH} 7.1,10 \mathrm{ml}$ per litre culture fluid) and the suspension subjected to ultrasonic treatment for $5 \mathrm{~min}$ under cooling $\left(-10^{\circ} \mathrm{C}\right)$, after which the fluid was centrifuged for $20 \mathrm{~min}$ at $3,000 \mathrm{rpm}$ and the supernatant for about $2 \mathrm{~h}$ more at $100,000 \mathrm{~g}$ (Spinco $\mathrm{L}$ ). The clear supernatant fluid was dialysed at $4{ }^{\circ} \mathrm{C}$ for $10-20 \mathrm{~h}$ against phosphate buffer $(0.05 \mathrm{~mol} / 1 ; \mathrm{pH} 7.5)$ and stored in aliquots at $-20^{\circ} \mathrm{C}$ (stock cytidine deaminase). The protein content was 5-12 g/l, the cytidine deaminase activity 3,000$7,000 \mathrm{U} / 1$, depending upon the growing conditions.

\section{Reagents}

\section{Buffer solution}

Dissolve $4.20 \mathrm{~g}$ sodium diethylbarbiturate and $6.30 \mathrm{~g} \mathrm{Mg}$ $\mathrm{SO}_{4} \cdot 7 \mathrm{H}_{2} \mathrm{O}$ in about $800 \mathrm{ml}$ of water. Adjust the $\mathrm{pH}$ to 7.50 with $1 \mathrm{~mol} / 1 \mathrm{HCl}$ and dilute to $1,000 \mathrm{ml}$.

2. Cytidine deaminase solution

Dilute the stock cytidine deaminase 10-30 times (depending on the batch activity) with buffer solution and dissolve $28 \mathrm{mg}$ disodiumphenylorthophosphate (British Drug Houses) per $10 \mathrm{ml}$ of this solution. (phenylphosphate concentration $11 \mathrm{mmol} / \mathrm{l}$.

Remains stable for a few days at $4{ }^{\circ} \mathrm{C}$.

3. CMP solution $(38.5 \mathrm{mmol} / \mathrm{l})$

Dissolve $458 \mathrm{mg}$ CMP (Boehringer; disodium salt: $6 \mathrm{H}_{2} \mathrm{O}$, free of cytidine) in $25 \mathrm{ml}$ buffer solution. Prepare just before use.

4. EDTA solution Dissolve $5.6 \mathrm{~g}$ ĖंTA (Dipotassium salt: $2 \mathrm{H}_{2} \mathrm{O}$ ) in distilled water and make up to $50 \mathrm{ml}$.

5. Concentrated phenol reagent

Dissolve $50 \mathrm{~g}$ phenol (A. R. grade) and $0.25 \mathrm{~g}$ disodium pentacyanonitrosylferrate (A.R. grade) in water and make up to 1 litre. Stable in an amber bottle at $4{ }^{\circ} \mathrm{C}$ for at least two months.

6. Concentrated alkali-hypochlorite reagent

Dissolve $25 \mathrm{~g}$ sodium hydroxide in $60 \mathrm{ml}$ distilled water. Add $72 \mathrm{ml} 0.5 \mathrm{~mol} / 1 \mathrm{NaClO}$ solution (e.g. British Drug Houses, in $1 \mathrm{~mol} / 1 \mathrm{NaOH}$ ) and make up to 1 litre.

Stable in an amber bottle at $4{ }^{\circ} \mathrm{C}$ for at least two months.

7. Working phenol/EDTA colour reagent

Dilute 1 volume concentrated phenol reagent with 4 volumes water. To $100 \mathrm{ml}$ solution, add $2 \mathrm{ml}$ EDTA solution. Prepare fresh before use.

8. Working alkali-hypochlorite reagent

Dilute 1 volume concentrated alkali-hypochlorite reagent with 4 volumes water. Prepare fresh before use.

9. Cytidine standard solution $(3.74 \mathrm{mmol} / \mathrm{l})$

Dissolve $92 \mathrm{mg}$ cytidine (Boehringer) in saturated benzoic acid and dilute to $100 \mathrm{ml}$. Stable for months at $4{ }^{\circ} \mathrm{C}$.

\section{Procedures}

The 5'-nucleotidase/ammonia method with CMP

a) Direct method

To a series of test tubes, add the amounts indicated in Table I. Before addition of the CMP, the tubes are placed in a $37^{\circ} \mathrm{C}$ waterbath for a few minutes. The reaction can now be started with the CMP, and after exactly $30 \mathrm{~min}$ stopped with the phenol reagent. After immediate addition of the alkali-hypochlorite reagent and mixing, the tubes are incubated for another $30 \mathrm{~min}$

The optical densities of the solutions can then be read at $625 \mathrm{~nm}$. The unknown $\left(A_{x}\right)$ is read against the unknown blank, the standard $\left(A_{s}\right)$ and the reagent control $\left(A_{c}\right)$ against the standard blank. All readings were made in a Zeiss PM 2 D spectrophotometer with a $10 \mathrm{~mm}$ flow-through cell.

In the calculation we use the equation:

$$
\frac{A_{x}-A_{c}}{A_{s}} \times 124.7=U / 1
$$

The factor $124.7=\frac{3.74}{10} \times \frac{10,000}{30}$, in which

3.74 is the concentration standard in $\mathrm{mmol} / \mathrm{l}(=\mu \mathrm{mol} / \mathrm{ml})$,

$\frac{1}{10}$ is the volume standard $(=0.1 \mathrm{ml})$,

10,000 is the sample volume of $0.1 \mathrm{ml}$, the activity being expressed per litre serum, and

$\frac{1}{30}$ is the incubation time of $30 \mathrm{~min}$, the activity being expressed per min.

\section{b) Indirect method}

For comparative purposes (see Comments under „Correlations with the AMP method") some sera were analyzed with an indirect method. Briefly, serum was incubated for $\mathbf{6 0}$ minutes with CMP in the absence of cytidine deaminase. A trichloroacetic acid solution was added to stop the reaction and precipitate the proteins. After centrifugation the supernatant was neutralized by the addition of phosphate buffer $(200 \mathrm{mmol} / \mathrm{l}, \mathrm{pH} 7,5)$. Cytidine deaminase was added to the mixture to deaminate cytidine. Separate experiments revealed that phosphate buffer $(200 \mathrm{mmol} / \mathrm{l})$ does not affect cytidine deaminase activity as compared to veronal buffer. The ammonia formed was measured as described under the direct method. The procedure is outlined in table II.

The unknown $\left(A_{X}\right)$ is read against the unknown blank, the reagent control $\left(\mathbf{A}_{c}\right)$ and the standard $\left(A_{s}\right)$ against the standard blank. Calculation of 5'-Nucleotidase activity:

$\frac{\mathbf{A}_{\mathbf{x}}-\mathbf{A}_{\mathbf{c}}}{\mathbf{A}_{\mathbf{s}}} \times 31.2=\mathrm{U} / \mathrm{l}$

The factor $=\frac{3.74}{10} \times \frac{5000}{60}$ in which

3.74 = concentration standard $(\mathrm{mmol} / \mathrm{l})$

0.10 = volume standard

$5000=$ to convert sample volume $(0.2 \mathrm{ml})$ to $1000 \mathrm{ml}$

$1 / 60=$ to express activity per minute.

\section{Determination of 5'-Nucleotidase activity with AMP}

This is done as described elsewhere (4).

\section{Determination of the cytidine deaminase activity}

Incubate $0.1 \mathrm{ml}$ cytidine deaminase stock solution (appropriately diluted, e.g. 40 times) with $1.0 \mathrm{ml} 10 \mathrm{mmol} / 1$ cy tidine solution in buffer. For a blank, take $0.1 \mathrm{ml}$ of the same diluted cytidine deaminase solution and $1.0 \mathrm{ml}$ buffer solution. Similarly, mix $0.1 \mathrm{ml}$ ammonium sulphate solution $(1.5 \mathrm{mmol} / \mathrm{l})$ with $1.0 \mathrm{ml}$ buffer solution. After $30 \mathrm{~min}$ of incubation at $37^{\circ} \mathrm{C}$, the . ammonia is determined as above with the Berthelot reaction. Read at $625 \mathrm{~nm}$ against a buffer blank.

Calculation of the cytidine deaminase activity:

$\frac{\left.A_{\mathbf{X}} \text { (Test-Blank }\right)}{\mathbf{A}_{\mathbf{S}}} \times 100 \times$ dilution factor $=\mathrm{U} / 1$

The factor $100=\frac{1.5 \times 2}{10} \times \frac{10,000}{30}$ is derived from:

1.5 : concentration of the ammonium sulphate standard ( $\mathrm{mmol} / \mathrm{l})$

2 : converts this to $\mathrm{NH}_{3}$

$\frac{1}{10} \quad$ : volume standard $=0.1 \mathrm{ml}$

$\frac{10,000}{30}:$ activity expressed per min per litre.

Determination of $S^{\prime}$-Nucleotidase activity (phosphate method) We used the Heppel and Hilmoe method (8), with a number of modifications (1), involving a reaction mixture of $3.2 \mathrm{ml}$, veronal buffer, a $30 \mathrm{~min}$ incubation time, and reduction with ammonium ferrous sulphate. 


\section{Comments on the procedure}

\section{Activity of cytitine deaminase}

For the determination of the $\mathrm{K}_{\mathrm{m}}$ value of cytidine deaminase for cytidine, a strongly diluted cytidine deaminase solution was used. The reaction rate was measured as a function of the cytidine concentration, covering the range $0.02-5.0 \mathrm{mmol} / 1$. From a number of Lineweaver-Burk plots, $\mathrm{K}_{\mathrm{m}}$ values between 0.21 and $0.27 \mathrm{mmol} / 1$ were calculated, which is in good agreement with the literature (9). Neither $K_{m}$ nor $V_{\max }$ was significantly influenced by the presence of $0.1 \mathrm{ml}$ serum or $5 \mathrm{mmol} / 1 \mathrm{CMP}$.

Increasing amounts of cytidine were incubated for 30 min with the given excess of cytidine deaminase solution (see reagents) and the resulting colour was compared with that of equimolar (with respect to $\mathrm{NH}_{3}$ ) ammonium sulphate solutions in buffer. Figure 1 shows that this calibration curve is linear up to at least 0.8 $\mu \mathrm{mol}$ cytidine in the test volume, corresponding to a serum $5^{\prime}$-Nucleotidase activity of $270 \mathrm{U} / 1$.

It can be concluded that cytidine is completely converted to ammonia under the conditions of the $5^{\prime}$ Nucleotidase assay.

Theoretically, with our method a serum with a $5^{\prime}$-Nucleotidase activity of $200 \mathrm{U} / 1$ will generate in $30 \mathrm{~min} 0.6$ $\mu$ mol cytidine. As an arbitrary value, we wished to add sufficient cytidine deaminase to give complete conversion of this amount in $5 \mathrm{~min}$. Increasing amounts of cytidine deaminase solution, diluted with buffer and cytidine to a final volume of $1.1 \mathrm{ml}$, were incubated for exactly $5 \mathrm{~min}$ at $37^{\circ} \mathrm{C}$ with $0.6 \mu \mathrm{mol}$ cytidine (final concentration $0.546 \mathrm{mmol} / \mathrm{l}$ ). After proper correction with blanks, the ammonia produced is shown in Figure 2. On the basis of these results and the separately

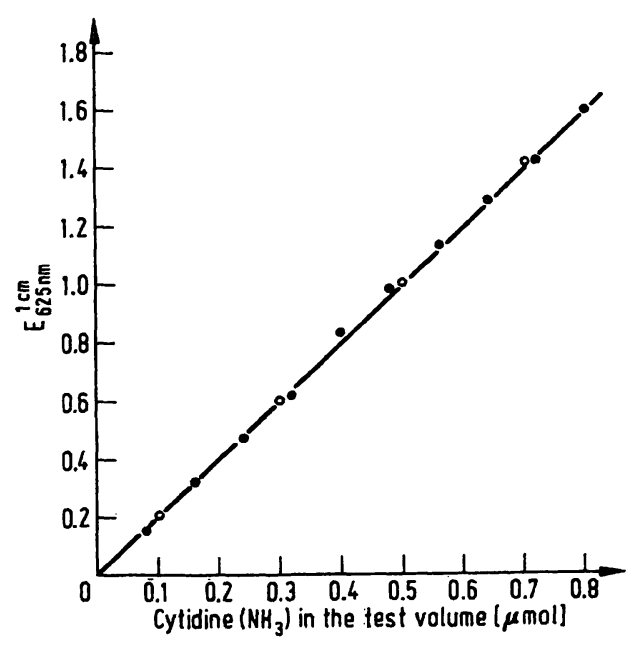

Fig. 1. Indophenol reaction; calibration curve obtained with cytidine in the presence of cytidine deaminase $(\bullet)$. Extinction values for some ammonium sulphate solutions in buffer, containing respectively $0.1,0.3,0.5$ and 0.7 $\mu \mathrm{mol} \mathrm{NH}{ }_{3}$, are shown for comparison (o).

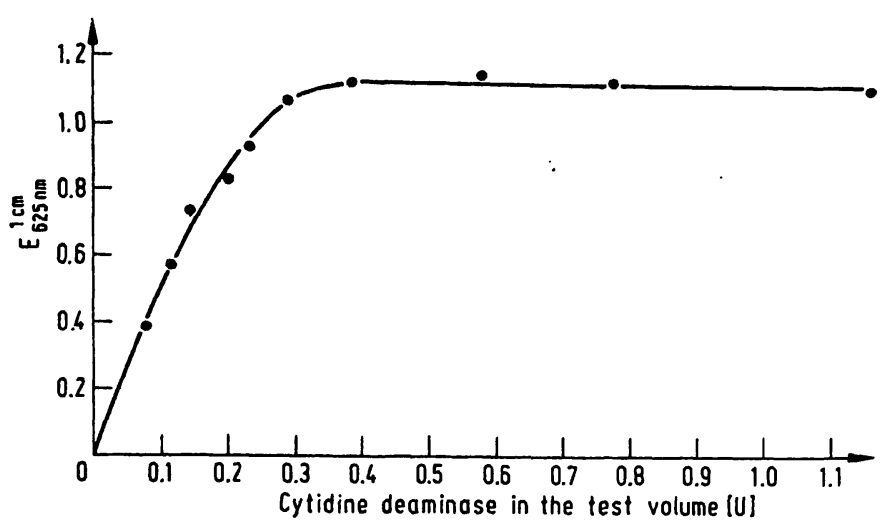

Fig. 2. Determination of the amount of cytidine deaminase for maximal 5 -Nucleotidase activity. Amount of cytidine corresponds to 5'-Nucleotidase activity of $200 \mathrm{U} / 1$ (Gencrating $0.6 \mu \mathrm{mol}$ of cytidine in $30 \mathrm{~min}$ ).

measured cytidine deaminase activity of the solution, at least $0.33 \mathrm{U}$ of cytidine deaminase activity has to be present in each tube to fulfil the above-mentioned criterion. However, we did most studies, and obtained good results, with $\pm 0.18 \mathrm{U}$ per test tube.

\section{CMP and $\mathrm{Mg}^{2+}$ concentration}

The relationship between the $5^{\prime}$-Nucleotidase activity and the CMP concentration is shown in Figure 3. A Lineweaver-Burk plot gave a $\mathrm{K}_{\mathrm{m}}$ value of $0.175 \mathrm{mmol} / \mathrm{l}$. For all further experiments a CMP concentration of $7.0 \mathrm{mmol} / \mathrm{l}$ was taken $\left(40 \times \mathrm{K}_{\mathrm{m}}\right)$.

Experiments designed to check this $\mathrm{K}_{\mathrm{m}}$-value by means of the $\mathrm{P}_{\mathbf{i}}$ determination gave principally the same results but were not exact. The reported experiments were always performed with added magnesium, to a final concentration of $24 \mathrm{mmol} / 1$, and Figure 4 shows that this concentration is high enough to give maximal stimulation.

\section{Linearity}

The time course of the $5^{\prime}$-Nucleotidase reaction performed according to Table 1 and shown in Figure 5, reveals linearity with the incubation time for more than $50 \mathrm{~min}$.

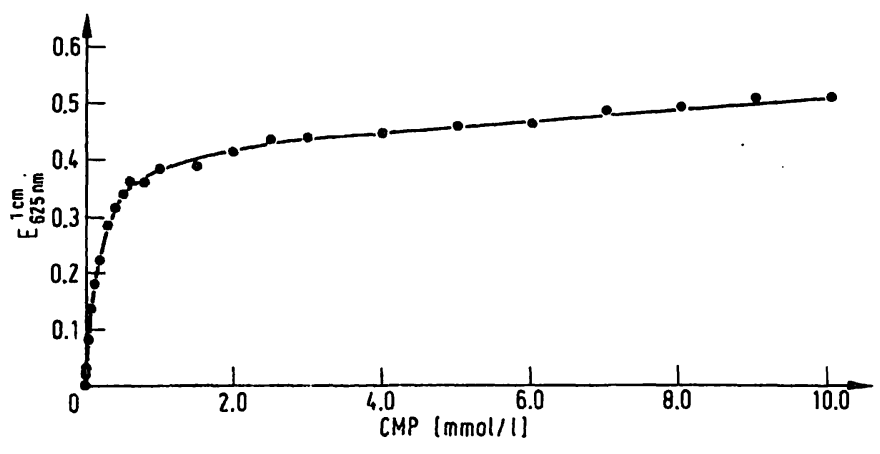

Fig. 3. Effect of CMP (final concentration) on $5^{\prime}$-Nucleotidase activity, according to table I. Serum 5'-Nucleotidase: $81 \mathrm{U} / \mathrm{l}$. 
Tab. 1. Procedure for the $5^{\prime}$-Nucleotidase determination (direct method)

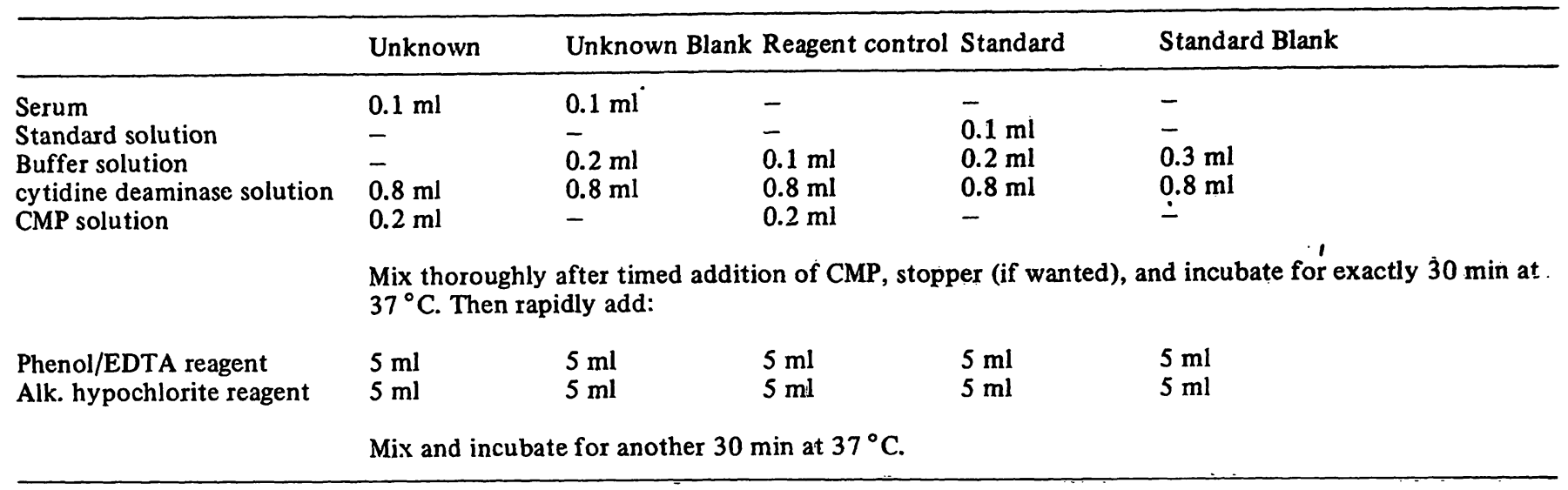

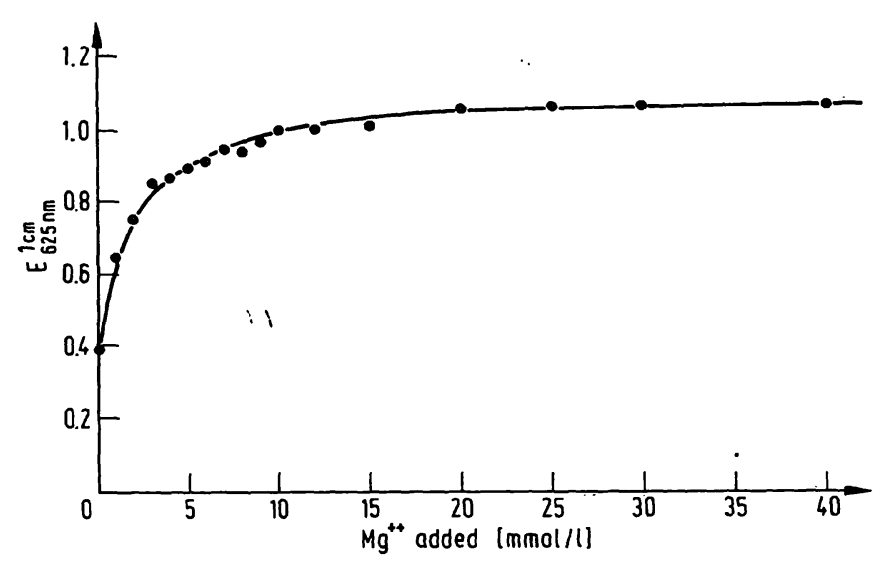

Fig. 4. Effect of added $\mathrm{Mg}^{2+}$ on the $5^{\prime}$-Nucleotidase activity. Serum 5'-Nucleotidase: $176 \mathrm{U} / \mathrm{l}$.

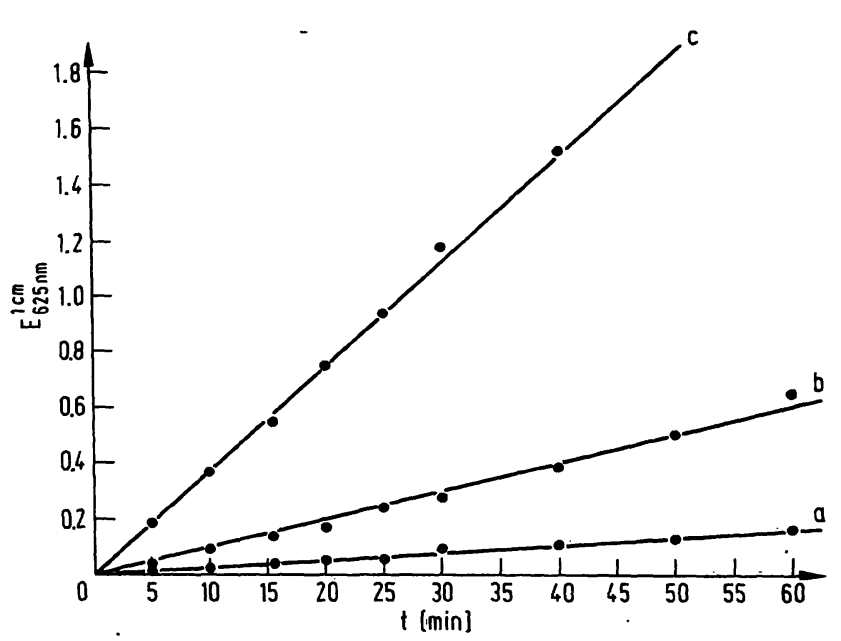

Fig. 5. Time course of $5^{\prime}$-Nucleotidase activity. Serum $5^{\prime}$-Nucleotidase: 14.9 (a), 51.8 (b), and 189 (c) U/l.

\section{Reproducibility}

To obtain an impression of the reproducibility of the assay, a serum with a $5^{\prime}$-Nucleotidase activity of $233 \mathrm{U} / 1$ (mean value) was tested in a tenfold assay in one series.
The standard deviation (S.D.) was $2.9 \mathrm{U} / 1$, from which a coefficient of variation (C.V.) of $1.2 \%$ was calculated. For a serum with a mean value of $53.5 \mathrm{U} / 1$ these values were $1.1 \mathrm{U} / 1$ and $2.1 \%$ respectively.

The C.V. was also estimated from the results of a number of serums analysed in duplicate (in several series). Arranged according to activity levels, these results are given in Table 3.

\section{Correlation with the AMP method (4)}

The principle of ,competitive substrate retention", described in a previous paper (3), was also studied for the present method. Three different serums were assayed for $5^{\prime}$-Nucleotidase activity, using different concentrations of phenyl phosphate. Figure 6 shows that $8.0 \mathrm{mmol} / 1$ phenylphosphate, the concentration used in the method according to Table 1 , is sufficient to inhibit the interference of alkaline phosphatase.

For comparison of the present direct method and the method according to 1.c. (4), sera were analysed in both ways. Figure 7 shows the results graphically. For the regression equation we calculated:

$\mathrm{y}(\mathrm{CMP})=1.86 \times(\mathrm{AMP})-4.24$.

Using the indirect method (Table 2) however, a relatively small intercept on the abcissa was found (Fig. 7).

Contrary to the results with the direct method, the value of $A_{c}$ was about zero. The reaction which is measured as $A_{c}$ in the direct method was found to increase with increasing concentrations of CMP or of our crude cytidine deaminase solution. The intercept could show a positive value up to $20 \mathrm{U} / \mathrm{l}$. Experiments were performed in which the $A_{c}$ reaction in veronal buffer was studied in the presence of serum dialyzed against physiological saline. The results clearly indicated that the $A_{c}$ reaction is inhibited by dialyzable serum constituents (details will be published in another report). 
Tab. 2. Procedure for the $5^{\prime}$-Nucleotidase determination (indirect method)

\begin{tabular}{llllll}
\hline & Unknown & \multicolumn{3}{l}{ Unknown blank Reagent control Blank } & Standard \\
\hline Serum & $0.2 \mathrm{ml}$ & $0.2 \mathrm{ml}$ & - & - & - \\
CMP solution') & $1.0 \mathrm{ml}$ & - & $1.0 \mathrm{ml}$ & - & - \\
Buffer solution & - & $1.0 \mathrm{ml}$ & $0.2 \mathrm{ml}$ & $1.2 \mathrm{ml}$ & $\cdots$
\end{tabular}

Mix thoroughly and incubate for 60 minutes at $37^{\circ} \mathrm{C}$. Then add:

Trichloroacetic acid solution $(30 \%)$
$0.2 \mathrm{ml}$
$0.2 \mathrm{ml}$

$0.2 \mathrm{ml}$

$0.2 \mathrm{ml}$

$0.2 \mathrm{ml}$

Let stand for 10 minutes, centrifuge off the precipitate.

Transfer $0.2 \mathrm{ml}$ in a tube Transfer $0.2 \mathrm{ml}$ supernatant and add:

in a tube an add:

\begin{tabular}{|c|c|c|c|}
\hline $\begin{array}{l}\text { Phosphate buffer }{ }^{2} \text { ) } \\
\text { cytidine deaminase solution }{ }^{3} \text { ) } \\
\text { Standard solution }\end{array}$ & $\begin{array}{l}0.8 \mathrm{ml} \\
0.1 \mathrm{ml} \\
-\end{array}$ & $\begin{array}{l}0.8 \mathrm{ml} \\
0.1 \mathrm{ml} \\
-\end{array}$ & $\begin{array}{l}0.8 \mathrm{ml} \\
0.1 \mathrm{ml}\end{array}$ \\
\hline
\end{tabular}

Mix and incubatc for 15 minutes at $37^{\circ} \mathrm{C}$.

$\begin{array}{llllll}\text { Phenol/EDTA reagent } & 5 \mathrm{ml} & 5 \mathrm{ml} & 5 \mathrm{ml} & 5 \mathrm{ml} & 5 \mathrm{ml} \\ \text { Alk. hypochlorite reagent } & 5 \mathrm{ml} & 5 \mathrm{ml} & 5 \mathrm{ml} & 5 \mathrm{ml} & 5 \mathrm{ml}\end{array}$

Mix and incubate for another 60 minutes at $37^{\circ} \mathrm{C}$.

${ }^{1}$ ) reagent 3 diluted with buffer solution to a concentration of $8.4 \mathrm{mmol} / \mathrm{l}$ of CMP

2) $200 \mathrm{mmol} / 1, \mathrm{pH} 7.5$

3) contains $0.18 \mathrm{U}$ cytidine deaminase

Tab. 3. Coefficients of variation (C.V.)

\begin{tabular}{llll}
\hline $\begin{array}{l}\text { Range of } \\
\text { 5'-Nucleotidase } \\
\text { activity (U/l) }\end{array}$ & $\begin{array}{l}\text { Number of } \\
\text { duplicates }\end{array}$ & $\begin{array}{l}\text { S.D. } \\
\text { (U/I) }\end{array}$ & C.V.(\%) \\
\hline $0-30$ & 22 & 1.3 & 8.7 \\
$30-80$ & 16 & 1.1 & 2.0 \\
$80-130$ & 11 & 2.6 & 2.5 \\
$130-450$ & 13 & 7.3 & 2.5 \\
\hline
\end{tabular}

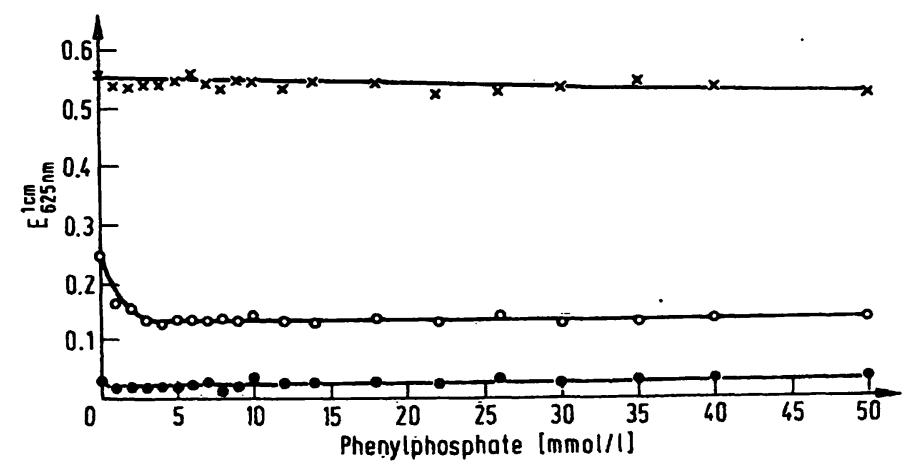

Fig. 6. Effect of various phenylphosphate ( $\mathrm{mmol} / \mathrm{l})$ levels in the incubation medium.

- normal serum ( $5^{\prime}-$ Nucleotidase: $4.0 \mathrm{U} / 1$ )

o serum of patient with Paget's disease (5'-Nucleotidase: $22.6 \mathrm{U} / 1$, alk. phosphatase: $2,200 \mathrm{U} / 1$ )

$\mathrm{X}$ serum with alk. phosphatase at $450 \mathrm{U} / \mathrm{l}$ (liver fraction, 5'-Nucleotidase: $90.8 \mathrm{U} / 1$ ).

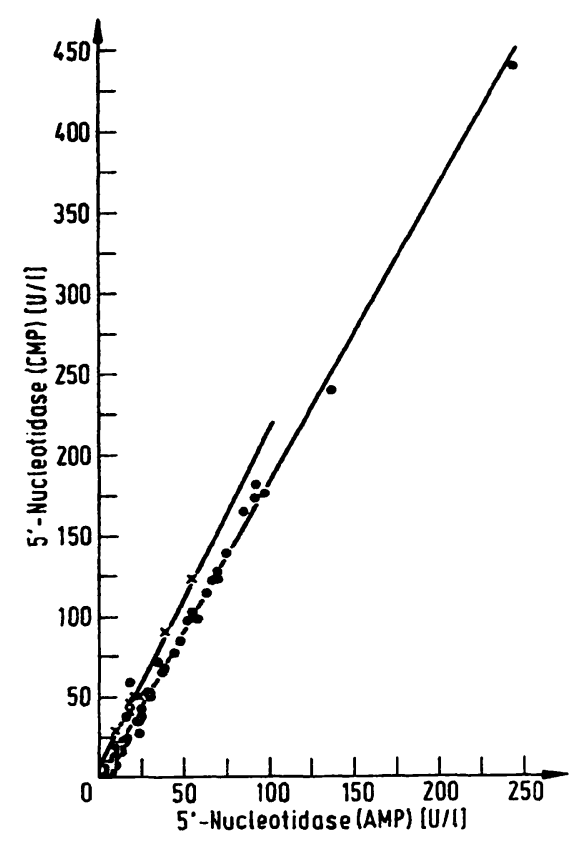

Fig. 7. Correlation between the two 5'-Nucleotidase methods (AMP or CMP as substrate).

Calculated regression equation:

$y=1.86 x-4.24$.

Correlation coefficient $r=0.996$ (direct method).

Calculated regression equation for the indirect method: $y=2.10 x+5.2 ; r=0,9951$

$\longrightarrow$ direct method, $\mathrm{x} \longrightarrow \mathrm{x}$ indirect method. 


\section{Properties of cytidine deam inase}

With respect to the source and isolation of cytidine deaminase, there are a few reports $(9,10)$, but these purifications were not so impressive and the recoveries were poor. We found that $E$. coli cells grown in minimal medium and harvested early in the exponential phase, gave the highest cytidine deaminase production.

Experiments with various conditions for growth and harvesting (other culture media, radiation with UV light, use of detergents, etc.) resulted in the present method.

Our cytidine deaminase solution can only be considered as a rather crude preparation. However, some experiments performed to evaluate the stability under various conditions, may nevertheless be of practical significance. We found that the diluted cytidine deaminase solution is stable for at least one day at room temperature; there was no loss of activity after incubation under our conditions for more than $60 \mathrm{~min}$ at $37^{\circ} \mathrm{C}$, while storage at $4{ }^{\circ} \mathrm{C}$ resulted in only $18 \%$ loss after four days. The cytidine deaminase stock solution can withstand lyophilization (residual activity at least $95 \%$, which compares very favourably with the $52 \%$ we found for adenosine deaminase).

\section{Discussion}

Difficulties such as the long incubation time, incubation at temperatures higher than $37^{\circ} \mathrm{C}$ or large sample volumes resulting in high blank values, encountered with the available methods $(11,12)$ for the automated determination of serum $5^{\prime}$-Nucleotidase, led us to look for a better and more sensitive method. We also tried to maintain the advantages and clinical significance of our earlier method (4): The use of phenylphosphate for the inhibition of non-specific alkaline phosphatase, and an auxiliary enzyme for simultaneous conversion of the product to ammonia, followed by the sensitive Berthelot reaction. The result is a manual method giving results which compare very well with those of the procedure using AMP as substrate, but the activities are now almost doubled, which makes it possible to cut the previous incubation time by half.
The fact that we used a crude cytidine deaminase preparation may explain why a plot of the regression equation definitely intercepts the abcissa in the direct method.

Apparently the application of $A_{c}$ in formula (1) is an overcorrection. This may be explained by assuming that the crude cytidine deaminase preparations contain an enzym which in veronal buffer in the presence of CMP causes a side reaction to occur, which is suppressed to some extent by serum. This leads to calculated $5^{\prime}$ Nucleotidase activities which are too low in the order of 5-20 U/1 (depending the dilution of the crude cytidine deaminase). It is evident that a direct method is the method of choice for the routine measurement of $5^{\prime}$-Nucleotidase activities with CMP but that the problem of overcorrection limits the routine application of this method.

There appear to be several approaches, however, to the solution of this problem:

a) purification of the crude cytidine deaminase preparation to eliminate the interfering enzyme b) preparation of a series of pooled sera to be analyzed for $5^{\prime}$-Nucleotidase activity both with the indirect method and the direct method. The differences found between both assays will give an estimate of the intercept value. The intercept value can be used for the calculation of true $5^{\prime}$-Nucleotidase activities of samples analyzed with the direct method. Studies on these points are in progress.

Nevertheless, it may be concluded from the present results that combination of the sensitivity of the Berthelot reaction with the use of CMP as substrate for $5^{\prime}$ Nucleotidase (which gives higher activities than AMP), has provided a valuable approach to better automated direct methods for 5 '-Nucleotidase.

\section{Acknowledgments}

The authors are greatly indebted to Dr. P. van de Putte of the Medisch Biologisch Laboratorium T.N.O. at Delft, for advice and help in the preparation of the cytidine deaminase extract. We thank Mrs. C. Kosterman for skillful assistance in some experiments. The Zeiss PM 2 D spectrophotometer was kindly made available by Siewers and Niessel, Amsterdam. 


\section{References}

1. Persijn, J.-P., van der Slik, W., Kramer, K. \& de Ruyter, C. A. (1968). This journal 6, 441-446.

2. Persijn, J.-P., van der Slik, W., Timmer, C. J. \& Bon, A. W. M. (1969). This journal 7, 199.

3. Persijn, J.-P., van der Slik, W. \& Bon, A. W. M. (1969). This journal 7, 493-497.

4. Persijn, J.-P. \& van der Slik, W. (1970). Clin. Enzym. 2, $108-112$.

5. Persijn, J.-P., van der Slik, W. \& Engelsman, E. (1972). This journal $10,77-85$.

6. Fioretti, E., Caulini, G., Magni, G. \& Feliciolo, R. A. (1972). Ital. J. Biochem. 21, 102-112.
7. Sullivan, J. M. \& Alpers, J. B. (1971). J. Biol. Chem. 246, 3057-3063.

8. Heppel, L. A. \& Hilmoe, R. J. (1951). J. Biol. Chem. 188, 665-676.

9. Cohen, R. M. \& Wolfenden, R. (1971). J. Biol. Chem. 246, 7561-7565.

10. Ipata, P. L., Cercignani, G. \& Balesteri, E. (1970). Biochemistry 9, 3390-3395.

11. Bethune, V. G., Fleisher, M. \& Schwartz, M. K. (1972). Clin. Chem. 18, 1524-1528.

12. Van der Slik, W., Persijn, J.-P. \& van Leeuwen, L. (1974), This journal 12, 121-123.
Dr. J.-P. Pcrsijn

Plesmanlaan 121

Amsterdam-Slotervaart 


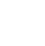

